\title{
The Social Construction of the Microfinance Industry: a comparison of donor and recipient perspectives
}

\author{
Arjun Bisen \\ Bronwen Dalton \\ University of Technology, Sydney \\ Rachel Wilson \\ University of Sydney
}

\begin{abstract}
Once driven fundamentally by development concerns, most importantly higher incomes for the poor, many scholars increasingly argue that microfinance "success" has become measured against the success of microfinance institutions themselves, gauged by their progress toward achieving financial self-sufficiency; a shift Gary Woller describes as a move from a welfarist to an institutionist model of microfinance. The regularity in which the institutionist position is articulated in most of the published literature in the field of microfinance is cited as evidence that institutionist perspectives have gained ascendancy over welfarist approaches (Woller 1999, p. 1). One key driver of this trend is the institutionist perspective's alignment with the interests of those with capital or in Bateman and Chang's (2009) words Microfinance's “supreme serviceability to the neoliberal/globalisation agenda” (2009, p.1). But to what extent is the ascendancy complete? Given the role of the media in framing public discourse and influencing public opinion, do institutionist or welfarist themes dominate the mass media, particularly in the major donor and recipient countries? This paper presents an analysis of media coverage of microfinance in one key donor country, the United States, and one major recipient country, India. It finds that while there are some differences in subject matter and style, overall both sets of media articles are dominated by business-oriented language, language that aligns with the institutionist view of microfinance. We argue that the microfinance community, in particular development focussed NGOs and agencies, have yet to come to terms with the implications of the emerging hegemony of the neoliberal institutionist world view. They face major and yet unresolved strategic challenges: Do these NGOs and agencies discard the welfarist model? Or can something be retrieved, if so what? Do they compete head on and become more commercialised themselves, or develop new methods and client bases, or do they exit? And what are the implications for academic understandings of the field - through institutionalism and welfarism - and to what extent do they shed light on the logic, or instead help obscure on-the-ground power relations? Given the dominance of institutionist thinking, we argue that welfarist oriented NGOs, agencies and academics must work together quickly and creatively to ensure that what began as a grassroots project to reduce poverty is not abandoned in favour of the pursuit of profit.
\end{abstract}

Microfinance has been one of the fastest growing "industries” of the new millennium, with the sector now containing over 10,000 microfinance institutions (MFIs) with over $\$ 60$ billion in assets (MacFarquhar 2010). This expansion has stimulated interest from both scholars and the mainstream media. There is a growing volume of academic research which broadly centres on two approaches: an "institutionist perspective" that highlights microfinance as an 
innovation in applying market solutions to social problems; and the other approach, often described as "welfarist", that questions the capacity of an increasingly commercialised sector to realise a mission of poverty reduction. But do these themes and concerns permeate academic boundaries? Specifically, does media coverage in key donor and recipient countries confirm or challenge or even engage with these debates?

To date much of this academic literature has overlooked how "microfinance” has been socially constructed in the public sphere through the mass media. This article compares how microfinance is framed in one major recipient country, India, and one key donor country, the United States, by conducting a media content analysis of 100 newspaper articles (sorted by level of relevance) that appeared in the top 10 highest circulating English language newspapers in the India and US over the 12 month period January-December 2008. We find that media coverage of microfinance in these two countries differed in various ways. The Indian media sample tended to focus on operational issues and report on specific business activity within the microfinance industry, in general treating it as a 'regular' part of the financial and banking system. US media articles often made broader generalizations about the industry, linking it to meta-narratives and broader themes - particularly microfinance as an innovation due to its harnessing of market forces to realize positive social outcomes. Despite these differences we find that overall both sets of media articles used business-orientated language. We argue that this is further evidence of the extent to which institutional change within microfinance, which started with a dominant development logic, has shifted to a market logic. This focus contrasts dramatically with the development focus of much academic debate about microfinance. It also has broader implications for development NGOs and ODA agencies and raises questions for future research. In particular: Do the agencies centred on development have a responsibility to condemn the widespread abuses of some Microfinance initiatives, and themselves discard the microfinance model? Or can something be retrieved, and, if so, what? Furthermore, what are the implications for academic understandings of the field and the perspectives of institutionalism and welfarism? To what extent do institutionism and welfarism shed light on the logic, or do they instead help obscure on-the-ground power relations? Microfinance has become the intervention of choice of the world's major international donors and aid agencies. Given the dominance of institutionist thinking, we argue that welfarist oriented NGOs and academics must work together quickly and creatively to ensure that what began as a grassroots project to reduce poverty is not abandoned in favour of the sole pursuit of profit. 


\section{The Microfinance Story}

Micro-lending has existed in various forms since the rise of formal financial systems (Brau \& Woller 2004). Examples of quasi-charitable micro-lending can be found throughout the nineteenth century in Europe and America (Hollis \& Sweetman 1998b). The current use of the expression 'microfinance' however can be traced back to the 1970s when Mohammad Yunus established the Grameen project in Bangladesh. Yunus established his first micro lending program in 1976 with the objective of providing a 'hand-up' rather than a 'hand-out' to the impoverished masses of Bangladesh by pioneering the so-called 'solidarity circles' methodology; wherein joint guarantees by groups of borrowers encouraged very high repayment rates on microloans as mechanism to sustainably provide hundreds of thousands of microloans to the very poorest (Yunus \& Jolis 2003). Yunus’ microfiance model of issuing small loans at interest rates of zero to 20 per cent with no collateral requirement was formalised into the Grameen Bank in 1983. The bank has now loaned more than $\$ 9.8$ billion and operates in over 100 countries. Despite having no collateral requirement or legal recourse against defaults, over 97 per cent of loans are repaid in full (Yunus 2005).

While the original generation of microfinance programs - Grameen Bank, BRAC, and Proshika - remain market leaders in terms of client numbers, other early entrants into this “industry” have become firmly established microfinance institutions (MFIs). The US government's USAID arm was an early champion of Yunus’ approach endorsing microfinance as 'best practice' (Bateman \& Chang 2009). In the late 1980s the World Bank began to provide significant support for new microfinance programmes and lead the establishment of CGAP (Consultative Group to Assist the Poor), a multi-donor institution that conscientously promoted the 'new wave' MFI concept. The UN also embraced the concept and funds microfinance initiatives through a number of its arms (e.g., UNDP, UNCDF) (Bateman \& Chang 2009). Other early entrants include ACCION International and SEWA Bank which both developed large microfinance programs. ACCION headquarters are in Boston but its operations span across Latin America and Africa. SEWA started as a cooperative bank in the Indian state of Gujurat. SEWA remains largely a Gujurat based operation which has expanded to include over 30,000 members. (CGAP 2003).

Now the microfinance field is characterised by a mix of several large, for profit service providers and numerous smaller nonprofit ones. Many of the large for profits are funded by an influx of capital market funding. By 2006, private investment funds, also known as 
microfinance investment vehicles (MIVs) held portfolios of MFIs' shares with a total value of $\$ 2.3$ billion (CGAP 2007). In the 2004-2006 period, foreign investment in Microfinance more than doubled, from USD 1.7 billion to around USD 4.4 billion (Deutsche Bank Research 2007).

Two events highlight microfinance's transformation from being viewed as a vaguely leftist idea of a Bangladeshi academic around the efficacy of assisting the poor through grassroots interventions, to becoming the poverty reduction methodology of "choice” for the world's largest international aid programs and wealthiest "socially minded” private foundations and investors. The first was in 2005, when the UN nominated the year the 'International Year of Microcredit'. Then Microfinance legitimacy as best practice was confirmed the following year, when Dr Muhammad Yunus and the Grameen Bank were jointly awarded the Nobel Peace Prize. As Shivani Siroya, CEO/Founder of the US based InVenture Fund, wrote in 2010 in The Huffington Post: "When Muhammad Yunus won the Nobel Peace Prize for his work at Grameen Bank, we all believed we had found a miracle tool that could help entrepreneurial individuals lift themselves out of poverty.”

Apace with this enthusiasm for microfinance programs from aid agencies and investors has been growing interest from within the academy. A large and growing volume of academic research has emerged much of it sharing the optimism of practitioners. However, within the microfinance literature a debate has also emerged which broadly centres on two approaches: an "institutionist perspective" that highlights microfinance as an innovation in applying market solutions to social problems; and the other approach, often described as "welfarist", that questions the capacity of an increasingly commercialised sector to realize a mission of poverty reduction.

\section{Institutionist perspectives on microfinance}

As the numbers of for profit financial institutions have increased in response to the lure of the massive profit potential of microfinance, a more diverse set of beliefs and ideological perspectives began to pervade the industry. Many of the larger and more recent entrants into the industry share an agenda based on neoclassical interpretations of economic development. Microfinance has come to be increasingly viewed as the perfect instrument for these new players to improve the lot of the poor and turn a profit - with the added benefit of improving 
an organisation's reputation for its commitment to Corporate and Social Responsibility (Hulme \& Mosley 1996, Otero 1999, Copestake 2007; Rhyne 2001).

In the US in particular, Microfinance is often projected as the ideal holistic approach to development, leading to outcomes such as the empowerment of women, financial inclusion, poverty reduction and overall development. This form of lending is often described as a pathway to self-sufficiency through entrepreneurship and as an example of the success of market-based alternatives to welfare government programmes. These initiatives are believed to create jobs, expand consumption and change attitudes towards entrepreneurship and business (Fernando 2004; Otero 1999; Bruck 2006; Ahlin and Lin 2006; Gonzalez 2007). However, overall 'success' of Microfinance has often come to be judged on the basis of the financial sustainability of the MFI itself (Woller 1999). This financial sustainability not only comes directly through profit generation but via other benefits, for example, an investment in microfinance can provide large financial organisations the opportunity for low risk portfolio diversification in volatile economic times (Krauss \& Walter 2009). As Elisabeth Rhyne, formerly at USAID and now managing director of the Center for Financial Inclusion at ACCION, writes in a 2008 article in The American Banker, "the crisis of confidence has highlighted what a good credit risk most microfinance clients have proven to be. Isolated in most cases from their countries' formal economies, the self-employed poor are also resilient during downturns. Indeed, microfinance may be a bright spot in the banking industry's future” (Rhyne 2009).

Collectively scholars have come to refer to proponents of market-based approaches to microfinance as falling under the umbrella of institutional perspectives and this support for 'market solutions to social problems' often is referred to as the "institutionist” approach. The terminology was initially applied to the microfinance literature by Jonathan Morduch in his influential paper 'Microfinance Schism' (1998) and further developed by Gary Woller and James Brau (Woller, Dunford, \& Woodworth 1999; Woller 2002; Brau \& Woller 2004).

The "institutionist” approach is characterised by arguments that successful poverty reduction requires massive scale, given the number of poor households and the demand for microfinance. This massive scale in turn requires financial resources far beyond the levels provided by traditional NGOs and aid donors. Instead they prescribe an approach where microfinance institutions that generate the highest return for investors attract the most capital 
with which to expand their business, service more clients, and therefore alleviate the most poverty are seen as examples of 'best practice’(Gonzalez-Vega 1994; 1998; Schreiner 2003; CGAP 2003, Ayayi \& Sene 2008).

Practitioners that subscribe to the institutionist approach cite the failed rural credit agencies of the 1960s and 1970s as proof that receiving subsidies in the form of aid is damaging to the microfinance industry (Hollis \& Sweetman 1998a; 1998b). They argue that the financial health of the institution is of the utmost concern. Success of the institution is measured by its progress towards financial self-sufficiency while the positive impact on the client is assumed (Hulme \& Mosley 1996; Otero 1999; Copestake 2007; Rhyne 2001).

\section{Welfarist perspectives on microfinance}

Despite this enthusiasm for microfinance, a growing number of scholars argue that microfinance has lost its way, deviating from the professed social objective to eradicate, or at least reduce, poverty in favour of a focus on generating profits (Woller, Dunford, \& Woodworth 1999; Woller 2002; Lewis 2008). They claim that microfinance does not reach the poorest of the poor (Scully 2004), or that the poorest are deliberately excluded from microfinance programs (Simanowitz 2002).

These scholars point to how sharp increases in interest rates and a tendency to extend larger average loan sizes to a more secure client base are signs of widespread mission drift. They point to the behaviours of some of the world's largest commercial microfinance institutions (MFIs) which operate with two bottom lines: alleviating poverty for clients and generating profits for investors. For example, one of Mexico’s largest not-for-profit microfinance entities, Compartamos ('let’s share' in Spanish) became Compartamos Banco, one of the country’s largest banks, after a 2007 IPO that raised over \$450 million. Yet, according to Lewis, the realization of Compartamos' commercial bottom line has come at the expense of its social mission. Compartamos' borrowers routinely pay annual percentage rates (APR) of more than 100 percent (Lewis 2008). Compartamos’ exorbitant charge has been blamed for excessive loan rates across all Mexican financial institutions (MacFarquhar 2010).

Welfarists argue that such developments signal that the movement, which broke away from traditional banking and economics in a bid to 'fix' the system, has come full circle; 
transforming into an industry that values commercialisation and adheres to conservative economic views. The critique of microfinance points out that the arguments for commercialisation are firmly based on conventional economic mechanisms such as markets, individual rational choice, and supply and demand. However, the critique also notes that it was these same economic mechanisms that pushed the poor, particularly the poorest, out of the system in the first place (Sinclair 2012; Bennett 2009).

Unlike the institutionist perspective, which emphasises breadth of outreach, the welfarist perspective focuses on depth of outreach and supports practices that allow microfinance institutions to serve the very poor, often cited as the original goal of the microfinance movement (Christen 2001). Welfarist scholars also argue that MFIs that can secure a regular stream of subsidies including untied aid can also be deemed institutionally viable (Murdoch 1998, Woller et al. 1999).

This debate is likely to continue, not least because of a lack of definitive evidence about the actual capacity of microfinance to alleviate poverty. Researchers around the world have only recently started measuring the actual long-term social impact of micro-lending and as Zeller and Meyer (2002) argue, microfinance field operations have far surpassed the research capacity to analyse them and that the enthusiasm for microfinance is unsupported by research evidence (Zeller \& Meyer 2002). Even Jonathan Morduch, the co-author of a major international textbook on the economics of microfinance and long time microfinance advocate, admits that, while economic theory suggests micro-finance has benefits, "[r]igorous evidence that shows it happening just doesn't exist ... The evidence is pretty dicey” (Morduch 2007). Nevertheless, there is evidence that the institutionist view has come to dominate the microfinance discourse. Woller writes that institutionist "emphasis on financial self-sufficiency and institutional scale, appears to have gained ascendancy over the welfarist approach, with its emphasis on direct poverty alleviation among the very poor.” (1999, p.1). He goes on to write:

The institutionist position is articulated in virtually all the literature coming out of the Ohio State University Rural Finance Program, the World Bank and the Consultative Group to Assist the Poorest (CGAP) in the World Bank, and USAID. It is also found in the many writings of Maria Otero (ACCION International) and Elisabeth Rhyne (formerly of USAID) (see, for example, 
Otero \& Rhyne, 1994). Most published literature in the field of microfinance espouses the institutionist view (Woller 1999, p. 1).

Woller et al. (1999) explain that institutionists speak the language of modern donors:

The institutionists have been more articulate and persuasive and certainly more prolific in their writing and their message has been more in tune with the times, the currently dominant culture of laissez-faire business (1999, p.3).

Milford Bateman and Ha-Joon Chang (2009) go further and argue that the key driver of the ascendency of the institutionist model is because it tacitly supports the neoliberal values of the most wealthy and in so doing bolsters the neoliberal globalisation project:

The final concern we have with the microfinance model is its intimate relationship with neoliberalism and the globalisation project...by emphasising individual entrepreneurship over all other forms (state, cooperative, etc), the microfinance concept has strong political/ideological serviceability to the prevailing neoliberal/globalisation model. This association is extremely problematic, because there is much evidence to suggest that policies and institutions could be deliberately favoured simply because they support neoliberalism and the globalisation project, and for no other reason than this (2009, p.6).

But to what extent is such an ascendancy complete? Has this debate permeated practitioner and academic boundaries? An as yet underexplored domain of public discourse remains to be analysed, that is the domain of the mass media. This is a significant gap in our understanding of the state of play between these competing schools of thought as the media is central to how societies frame public discourse and interpret ideas. Phillips (1996) writes that the concept of 'discourse' depicts language “as a site of struggle and a medium for the exercise of power" (1996, p.150). Gamson argues that the discourses in mass media as a reflection the wider symbolic tussle over meaning and interpretations in society (Gamson 1988). By representing particular discourses, the media can tacitly endorse certain perspectives while silencing others by not giving them a voice. It is the main medium through which views expressed in the public sphere are conveyed to a wider public. Given such responsibility, it is important to be aware of media constructions surrounding microfinance as a way of not only appreciating wider discourse but also how the media or other groups may slant this discourse in ways that influence individuals' and organisations' perceptions of their own interests. So do institutionist or welfarist themes dominate, particularly in the media of major donor and recipient countries? 
Given the significance of the media to inform and even shape interpretations of microfinance in the public sphere, it is insightful to analyse the content of media in one key donor country, the United States and one major recipient country, India.

\section{Media content analysis methodology}

We conducted a media content analysis of 200 newspaper articles that appeared in the top 10 highest circulating English language newspapers in India and the US over a 12 month period January-December 2008. The articles were retrieved using the web tool Factiva ${ }^{\mathrm{TM}}$.

\section{Sampling strategy and design for articles}

The analysis sampled 100 articles each from the US and India sorted by relevance that appeared between 1 January to 31 December, 2008. The query not only used the general name for the industry, 'microfinance', but also the most common services provided by microfinance institutions in order to cover almost all possible references to microfinance. This process also allowed a large number of media articles to be reduced to a more manageable sample (Riffe et al. 2008). The search initially generated 357 articles from the USA and 212 from India. To assist comparisons, the number of sample articles was reduced to 100 from each of the two countries, with each article selected according to relevance, determined by word frequency using Factiva.

\section{Coding operation}

Coding was conducted to convert the raw data into a standardised form (Babbie 2003). Little, if any, research has been undertaken on media representations of microfinance so the coding categories were developed in an inductive and exploratory way. Coding categories of both manifest and latent content were created to balance out their respective shortcomings. The software package NVivo 8 by QSR was used to code both types of content.

The surface, or manifest, content categories are specific words. The manifest content is analysed first, using word frequency query available in NVivo 8, to gain an understanding of some of the common language used. Some 500 of the most commonly occurring words from both countries were extracted and grouped into categories. The remaining words were cross checked between the two countries' media samples and word searches were run on any words 
that only qualified for one country's top 500 'word frequency' search. This was done so that comparable tables and graphs could be made.

\section{Rationale behind selection of India and the US}

The US and India were selected because they are major players in the microfinance industry. The US hosts the majority of donor coordinating agencies and large intergovernmental agencies proving microfinance outside of the developing world. Agencies such as Grameen Foundation US, USAID, ACCION, CGAP, the World Bank and the Microcredit Summit Campaign are all based in and raise much of their funds in the US and these funds constitute the majority of funds flowing within the industry. Due to the volume of funds at their disposal, the breadth and reach of their programs and, more generally, their central role in the global financial system, these agencies play a significant role in shaping microfinance policy and practice.

India was chosen for four primary reasons. Firstly, it has the largest number of MFIs and recipients of microfinance in the world. India and Bangladesh constitute approximately 60 per cent of the world's microfinance activity, making them the two largest nations in which microfinance is practised (Campaign 2007). Regionally the highest concentration of microfinance clients was in India (188 million accounts representing 18\% of the total national population). Secondly, compared to other recipient and MFI industry countries, India offers a practical advantage in terms of conducting comparative analysis as, unlike other recipient countries, India has a significant number of English language publications, and these publications are more readily accessible for analysis through the media search engine Factiva $^{\mathrm{TM}}$. The implications of differences in Indian and American English for the analysis are discussed later. Nevertheless, these differences notwithstanding, this shared language makes India the most suitable recipient country for comparison with the US. Finally, scholars of West Asia argue that India's news industry, in particular the large privately owned component of that industry, has a strong tradition of editorial freedom. Metcalf argues that it was only during the state of emergency declared by Prime Minister Indira Gandhi (1975 1977), that India's media was exposed to any significant government intervention and retribution (Metcalf 2006).

Limitations in comparative media analysis of Indian and US media: Elite readership and linguistic and stylistic differences

India's print media industry has expanded significantly in recent decades. In 2011 The 
Economist citing World Association of Newspapers figures wrote that: "Between 2005 and 2009 the number of paid-for daily newspapers in [India] increased by $44 \%$ to 2,700 and the total number of newspapers rose by $23 \%$ to more than 74,000 (The Economist 2011). The largest print media organisations of India are The Times of India Group, the Hindustan Times Group, the Indian Express Group, and the Anandabazar Patrika Group of which all, except the latter, publish English and vernacular versions of each issue (Metcalf 2006). Table 1 below shows the top 10 daily English language newspapers along with their total readership. The top five most popular newspapers listed are also printed in the vernacular.

\begin{tabular}{|c|c|c|c|}
\hline \multicolumn{5}{|c|}{ Table 1: Top 10 English Dailies } \\
\hline Rank & Newspaper & $\mathbf{2 0 0 7}$ & $\mathbf{2 0 0 8}$ \\
\hline 1 & The Times of India & $13,400,000$ & $13,332,000$ \\
\hline 2 & Hindustan Times & $6,092,000$ & $6,347,000$ \\
\hline 3 & The Hindu & 5,253000 & $5,276,000$ \\
\hline 4 & The Telegraph & $3,040,000$ & $2,970,000$ \\
\hline 5 & Deccan Chronicle & $2,987,000$ & $2,823,000$ \\
\hline 7 & The Economic Times & $1,986,000$ & $2,006,000$ \\
\hline 9 & The New Indian Express & $1,875,000$ & $1,825,000$ \\
\hline 10 & Mumbai Mirror & $1,627,000$ & $1,622,000$ \\
\hline
\end{tabular}

(Source: Newswatch 2008)

Despite these large numbers there are some limitations associated with analysing only Indian newspapers printed in English. While India has 90 million English speakers giving it the second largest population of English speakers in the world, this figure only makes up 10.66 per cent of the overall population with less than a quarter of a million people considering it their first language (Census of India 2003). Moreover English language speakers are unlikely to be representative of recipients of microfinance.

There are several characteristics that set consumers of English language media apart from the majority of India's population. Firstly, 70 per cent of all Indians live in rural communities 
(Indian Census 2003) but all of the English language publications have a geographic focus on major commercial cities. For example, The Times of India is Mumbai centric while The Hindustan Times is New Delhi focused. This suggests that most of the readers of English language newspapers are city dwellers and less directly affected by rural issues.

A more significant difference centres on class background. In her paper titled 'Colonial Interventions and the Postcolonial Situation in India', Parameswaran (1997) described the Indian media as a mechanism of the post-colonial caste system. She identifies a strong "Upper-class bias of the English-language media in India” (1997, p.1). She goes on to argue that India’s English-language media “articulate and support the interests and ideology of the English-educated urban upper/middle classes” (ibid.). Other scholars such as Ramanathan (2005), Annamalai (2004), Kumar (2003) and Scrase (2004) have also explored power, education and class dimensions of the use of English in India.

By contrast, the media of choice among those in poorer rural areas tends to be local vernacular newspapers. If the media is seen as a reflection of its audience's values then this content analysis is comparing the views of India's, and perhaps to some extent America's, elite. This has implications for any media analysis, in particular it could explain if media reports are biased in favour on investors and MFIs themselves rather than their clients. Another limitation is comparative media analysis between the countries is that there is significant linguistic and stylistic differences between Indian and US journalism. The Indian media sample largely reflected the findings of Peer (2007) in that most articles were very short. Since articles were shorter and less descriptive, the word counts were consistently lower for the Indian sample. We also found that 55 per cent of the articles on microfinance appeared in the business pages. By contrast, the US sample articles were much longer, more descriptive and covered broader themes and appeared in the general news section. Thus the US sample outscored the Indian sample in both word count for specific words and number of articles containing specific words.

Rationale for development of categories relating to NGO / development oriented words and commercial/ economic categories.

In an attempt to be as inductive as possible, categories were developed on the frequency of the top 500 words that appeared in all the articles in the sample. However, it is important to acknowledge that the grouping together of categories was problematic. Some were created 
based on synonyms; some around terminology such as economic terminology; or types of languages such as commercial language; others were based on a thematic orientation or association. Some groupings were tenuous and there was a degree of overlap. For example, the word 'philanthropy' has been placed in the 'aid' category and not the 'NGO' category. There are many ways in which the data can be arranged, nevertheless, it is argued that this inductive approach to compiling these categories provided at least some insight into media representations of issues relating to microfinance.

Based on the institutionist and welfarist theoretical frameworks, commercial language can be viewed as representative of institutionist orientations while development and NGO oriented language can be seen as emblematic of a welfarist orientation.

\section{Media Discourse of Microfinance}

\section{Manifest Coding}

The relative frequency of words in eight different categories is shown in Table 2. Out of the eight categories, three categories were categorised as relating to the welfarist perspective:

- Development oriented words (Development oriented help develop* need* peace);

- Aid and philanthropy oriented words (philanthrop*, donat*, aid, donor(s)) and

- $\quad$ NGO oriented words (Community, mission, non profit, NGO(s), foundation).

The remaining five were considered to fall under the umbrella of commercial language which aligns with the institutionist perspective:

- 4. Financial expansion/ growth’ oriented (access, large* reach, big*, expan* );

- 5. Financial viability and sustainability oriented (sustain* return profit*);

- 6. Other commercial language (strategy, private management business* capital, director, CEO, company, commercial, corporate, enterprises, executive);

- 7. Investor oriented (invest*, equity, fund(s) portfolio);

- 8. Other economic terminology (Regulation, market*, econom*). 
Table 2: Average word count summary for USA and Indian articles

\begin{tabular}{|c|c|c|c|}
\hline Category & Words & $\begin{array}{l}\text { India Average } \\
\text { Word Count }\end{array}$ & $\begin{array}{l}\text { US Average } \\
\text { Word Count }\end{array}$ \\
\hline 1. Development oriented & $\begin{array}{l}\text { Help, develop*, need*, peace, } \\
\text { poverty, support, poor, social rights }\end{array}$ & 47.1 & 152.9 \\
\hline $\begin{array}{l}\text { 2. Aid \& Philanthropy } \\
\text { oriented }\end{array}$ & $\begin{array}{l}\text { philanthrop*, donat*, aid, donor(s) } \\
\text { grant(s) }\end{array}$ & 5 & 33.8 \\
\hline 3. NGO oriented & $\begin{array}{l}\text { Community, mission, NGO(s) non- } \\
\text { Profit, NGO, foundation }\end{array}$ & 14 & 54 \\
\hline $\begin{array}{l}\text { 4. Financial expansion/ } \\
\text { growth oriented }\end{array}$ & $\begin{array}{l}\text { Access, large*, reach big*, expan* } \\
\text { Increase, grow* }\end{array}$ & 41.3 & 91.3 \\
\hline $\begin{array}{l}\text { 5. Financial Viability and } \\
\text { sustainability oriented }\end{array}$ & sustain*, return profit* & 27 & 64.7 \\
\hline $\begin{array}{l}\text { 6. Other Commercial } \\
\text { language }\end{array}$ & $\begin{array}{l}\text { Strategy, private management, } \\
\text { business*, capital, director, CEO } \\
\text { company , commercial, corporate, } \\
\text { enterprises, executive, } \\
\text { entrepreneur* }\end{array}$ & 38.8 & 89.2 \\
\hline 7. Investor oriented & invest*, equity fund(s), portfolio & 64.3 & 161 \\
\hline $\begin{array}{l}\text { 8. Other Economic } \\
\text { terminology }\end{array}$ & $\begin{array}{l}\text { Regulation, market*, econom* } \\
\text { demand competit* }\end{array}$ & 32.4 & 93.6 \\
\hline
\end{tabular}

The categories which registered the highest results in both samples in terms of total word count, average word count, number of articles containing words and number of words in each category (from highest to lowest ) were: 7. Investor oriented development; 8.Other Economic terminology, and; 4. Financial expansion/ growth’ oriented categories. All are examples of commercial language associated with the institutionist perspective. The lowest word counts were in the categories: 2. Aid and Philanthropy oriented, and; 3. NGO oriented, particularly in the Indian sample where many of the words did not appear in the top 500 list of most frequent words. Thus, the manifest content results show that institutionist language dominated both media samples, while welfarist language was used infrequently, particularly in the Indian media sample. Each of these categories is briefly discussed below.

\section{Institutionist Themes}

The most popular categories covered issues related to MFI operations and performance or investor orientation. This is significant as it indicates that the focus of most articles from both samples is likely to be on investors and MFIs themselves rather than their clients. Based on 
the samples, it appears that newspaper readers from both countries are largely exposed to language of investment and commerce in microfinance, which in turn may mean that readers are from an investing class and thus interested in this type of information and themes.

\section{Financial expansion/ growth’ oriented category}

Financial expansion or growth is essentially an element of outreach as well as the expansion and growth of the institution. Growth related words were used relatively frequently in both samples. In terms of total word count, this category was fourth highest in the US sample and third highest for the Indian sample. Both institutionists and welfarists believe in the importance of growth to different extents. Opinion falls along the spectrum from those scholars who argue that impact is most important to those who argue it is entirely about outreach and growth. The institutionists tend to emphasise that expansion and outreach of the MFI is paramount. While welfarists focus on impact over growth. The frequency with which financial expansion or growth and its synonyms were mentioned suggests an institutionist orientation in the media samples of both countries. Methods for funding growth shed greater light on other themes in both media samples.

\section{Investor oriented}

Despite only four words falling into this category, the average word count for investororiented words was the highest for both samples. Investor language was used far more frequently than aid or philanthropy oriented words, which was the most infrequently referenced category in both samples. Based on the sample, investment was the most frequently mentioned funding source for MFIs. This is indicative of an institutionist orientation within articles from both samples as investment and capital markets are an important concept in the institutionist worldview. Institutionists see capital markets as the only source of funding large enough to satisfy demand. Investing in MFIs also requires that the institution is viable and profitable.

\section{Other Commercial language}

In the 'Other commercial language' category most of the words were focused on MFI operations and described employees in a commercial sense. Results for words deriving from 'business' were particularly high. The abundance of commercial language in this study can be interpreted as an institutionist orientation to the majority of articles from the sample, further 
supporting Woller et al.'s (1999) notion of prolific and persuasive propagation of institutionist thought.

\section{Other Economic terminology}

The results from the manifest data demonstrated significantly higher results in this category for the US sample over the Indian sample, particularly for words deriving from market and economy. This largely aligns with Ferraro et al.’s (2005) argument on classical economics resonating more with American meta-narratives around individualism and the rags to riches motif (Lyotard 1984; Stephens \& McCallum 1998).

\section{Welfarist themes}

\section{Development oriented}

The second most populated category incorporated words associated with development. These words acknowledge to various extents the act of poverty alleviation and assistance. As expected when discussing microfinance, words associated with development are likely to be commonly used. The total word count made this category the highest for the US sample and second highest for the Indian sample. The results were relatively higher for the US sample (325 per cent higher). This result could tenuously suggest a concern for impact which forms the basis of the welfarist paradigm. However, another explanation could be that the frequency of words in the US sample over the Indian sample can partly be explained by the tendency for US journalists to link microfinance to broader themes and meta-narratives such as the rags to riches ‘American dream'.

\section{NGO oriented}

The category 'NGO Oriented' accounted for the second lowest related word counts. Morduch (1999) argues that those who sympathise with NGO and donor language values are primarily influenced by the welfarist perspective. Based on this, the media samples from both countries are unlikely to have a strong welfarist orientation, particularly the Indian sample which rarely used NGO terminology. The low results for both samples are particularly surprising considering the large number of MFIs that are NGOs.

\section{Aid and Philanthropy oriented}

US articles concerned with aid, philanthropy and serving the poorest were relatively few when compared to the commercial themes outlined above. Three out of nine articles that 
referred to aid argued that aid programs were ineffective. The six other articles described microfinance in aid projects or microfinance and aid having similar goals.

The Indian articles mentioned philanthropy only 11 times, broadly covering individual philanthropy and elements of venture philanthropy and Corporate Social Responsibility (CSR). An extract from a The Times of India suggests a greater need for philanthropy rather than referring to existing philanthropic practices.

There is a need for seeing very wealthy people in India beginning to understand that it is their responsibility to deal with poverty issues and then to provide grants, charity as people are doing in Hong Kong, Brazil, Mexico and China. Wealthy national citizens provide foundations that support. "Wealthy citizens should donate" The Times of India 11 September 2008.

\section{Discussion regarding content analysis}

The concept of a commercial industry was evident in the US press by continual references to microfinance in a business and finance context. Half of the US articles discussed microfinance in this context. The commercial orientation of many of these articles is evident in the following quotes:

Barnevik says he isn't just helping poor people, he is building businesses. "Everything I learned as a CEO applies in this world as well," he says. This is about business, not charity. It's about giving people capital and tools. Colvin, Geoffrey “A CEO Masters Micro-Credit” The Washington Post 23 December 2008

We'll see a marriage between microfinance and the corporate sector, and that marriage will prevail.

Maria Otero, ACCION president quoted PRNewswire/ May 12008

It is important that government policies reinforce the microfinance sector and not convert them into instruments of social policies, no matter how well intentioned these are.

Princess Maxima of the Netherlands quoted in ENP Newswire, 23 April 2008.

It would be remiss to imply all coverage of microfinance in the US has provided an unquestioning endorsement of the institutionist view microfinance and not to point to some more recent articles in high profile US publications. In particular, a front page New York 
Times story faulted lenders for profiting off the backs of borrowers (MacFarquhar 2010) and in 2010, the Wall Street Journal reported that as many as 30 micro-borrowers in India had committed suicide over looming, debilitating debt (Bellman \& Chang 2010).

The Indian sample also mentioned sustainability and commercialisation regularly with 56 per cent of the articles alluding to microfinance within a business context and treating it as a business and a commercial industry. Out of these, 29 per cent reported on non-banking financial institutions; 9 per cent covered MFIs partnering with commercial businesses; and 7 per cent on commercial banks with microfinance operations.

There were comparatively far fewer articles that focused on the development aspects of microfinance. Half of the US articles referred to some kind of development impact caused by microfinance while only 44 per cent of Indian articles associated microfinance with development. US articles concerned with aid, philanthropy and serving the poorest were relatively few when compared to the commercial themes above. Three out of nine articles that referred to aid felt the practice of aid was ineffective and propounded a bottom-up approach instead of a traditional top-down approach to development. The six other US articles described microfinance in aid projects or microfinance and aid having similar goals. The Indian articles didn’t refer to international aid but addressed philanthropy 11 times.

\section{Conclusions}

Little scholarly attention has been given to differences in the way the media, the donor and recipient aid communities have framed the contested concept of microfinance. In this article a comparison of how microfinance is framed in the US and Indian media provides some insights into the differences and similarities in the way microfinance is socially constructed in these two countries. This content analysis of the top 100 articles in each country relating to microfinance shows that the Indian media sample tended to focus on operational issues and report on specific business activity within the microfinance industry, in general treating it as a 'regular' part of the financial and banking system, while the US media sample made broader generalizations about the industry, linking it to meta-narratives -particularly microfinance as an innovation due to its harnessing of market forces to realise positive social outcomes. However, we found that market-based interpretations dominated both the US and Indian media samples. This dominant business-orientated rhetoric in both sets of media contrasts 
dramatically with the development focus of much academic debate about microfinance. Instead it demonstrates the extent to which microfinance has become subsumed in a larger set of commercial imperatives. In this way this finding contributes not only to our understanding of the differences in interpretations of microfinance between donor and recipient countries but also offers insights into the power relations at play within the microfinance industry and the broader development and business community.

The analysis also has broader implications for development NGOs and ODA agencies and raises questions for future research. In particular: In what ways can organisations reform or discard the current micro-finance model? And; are the academic understandings of the field, conceptualised as institutionism and welfarism, helpful heuristics? Do they shed light on the logic behind MFI operations? Or do they instead neglect the on-the-ground realities of power relations, competitiveness and instability in current global economic climate? These questions seek to clarify the mission of MFI organisations and ways that they can best fulfil their mission. The media analysis here highlights the need to continually question the missions and means of these organisations within the shifting social construction of their work.

Donors, governments, and NGOs will need to reconsider their strategies in new circumstances. In its establishment phase, microfinance was been driven fundamentally by development concerns, most importantly higher incomes for the poor. Now the financial sustainability of MFIs themselves has taken centre stage. The more traditional players of the microfinance community have yet to fully come to terms with the implications of such a shift. Commercialization and competition in microfinance pose challenges to NGOs as great as any they have faced in the past. NGOs may have to make major strategic changes. Relative to commercial entrants, NGOs’ major advantages are commitment to their mission and knowledge of their client base. NGOs may wish to consider how best to use those advantages in competitive situations. Planning for the future NGO leaders will face some tough decisions about whether to compete head on, become more commercialised themselves, develop new methods and client bases or exit the industry. Given the dominance of institutionist thinking, welfarist oriented NGOs and academics must work together quickly and creatively if they are to become an effective counterweight to the hegemony of the institutionist worldview to ensure that what began as a grassroots project to reduce poverty is not abandoned in favour of the pursuit of profit. 


\section{References}

Ahlin, C. \& Lin, J. 2006, Luck or Skill? MFI Performance in Macroeconomic Context, BREAD Working Paper no. 132.

Annamalai, E. 2004, 'Medium of power: The question of English in education in India', in J.W. Tollefson \& A.B.M. Tsui (eds.), Medium of instruction policies: Which agenda? Whose agenda? Lawrence Erlbaum Associates, Mahwah, pp. 177-194.

Ayayi, A. G. \& Sene, M. 2008, 'What Drives Microfinance Institution Financial Sustainability’, Microfinance Chair of Groupe Banque Populaire working paper.

Babbie, E. 2003, 'Lessons learned from teaching qualitative methods', Qualitative Research Journal, Special Issue 2003, pp.12-23

Bateman, M. and Chang, H.J. 2009, ‘The Microfinance Illusion’, http://www.econ.cam.ac.uk/ faculty/chang/pubs/Microfinance.pdf

Bellman, E. \& Chang, A. 2010, 'Backlash in microlending', Wall Street Journal October 22.

Bennett, D. 2009, 'Small change: billions of dollars and a Nobel prize later, it looks like 'microlending' doesn't actually do much to fight poverty', The Boston Globe, 20 September.

Brau, J. \& Woller, G.M. 2004, 'Microfinance: a comprehensive review of the existing literature', Journal of Entrepreneurial Finance and Business Ventures, no. 9, pp. 1 - 26.

Bruck, C. 2006, 'Millions for millions', The New Yorker, October issue

Campaign, M. S. 2007, 'State of the Microcredit Summit Campaign Report 2007'.

Census of India 2003, Issue 10: pp 8-10, www.censusindia.net

CGAP 2003, 'The new vision of microfinance: Financial services for the poor, The History of Microfinance', Prepared for CGAP UNCDF Donor Training.

CGAP 2007, CGAP Brief, Washington DC.

Christen, R. P. 2001, 'Commercialization and Mission Drift', Occasional Paper, CGAP, Washington.

Copestake, J. 2007, 'Mainstreaming microfinance: social performance management or mission drift?’ World Development, vol.35, no. 10, pp. 1721-1738.

Deutsche Bank Research 2007, Microfinance: an emerging investment opportunity, Deutsche Bank, Frankfurt am Main.

The Economist 2011, 'Bulletins from the future, July 7 http://www.economist.com/node/18904136

ENP Newswire 2008, Princess Maxima of the Netherlands and IDB President Inaugurate Seminar on Microfinance and Inclusion, 23 April 2008.

Fernando, N. A. 2004, 'Microfinance outreach to the poorest: A realistic objective?', Asian Development Bank: A Quarterly Newsletter of The Focal Point For Microfinance, vol.5, no.1.

Gamson, W. 1988, 'Political discourse and collective action' in B. Klandermans, H. Kriesi and S. Tarrow (eds), From Structure to Action: Comparing Social Movement Research Across Cultures, JAI Press, pp. 219-246.

Gonzalez, A. 2007, Resilience of Microfinance Institutions to National Macroeconomic Events: An Econometric Analysis of MFI Asset Quality, MIX Discussion Paper no. 1.

Hollis, A. \& Sweetman, A. 1998a, 'Microcredit in prefamine Ireland." Explorations in Economic History vol.35, pp. 347-380

Hollis, A. \& Sweetman, A. 1998b, 'Microcredit: What Can we Learn from the Past?' World Development, vol. 26, no.10, pp. 1875-1891.

Hulme, D. \& Mosley, P. 1996, 'Microenterprise finance: Is there a conflict between growth and poverty alleviation?’ World Development, vol. 26 no. 5, pp. 783-790. 
Krauss, N., Walter, I., 2009, ‘Can Microfinance Reduce Portfolio Volatility?’ Economic Development and Cultural Change, vol. 58, no.1, pp.85-110.

Kumar, J. 2003, Newspaper Marketing in India: A Focus on Language Press, Anmol Publications. Lewis, J. C. 2008, 'Microloan Sharks', Stanford Social Innovation Review vol. 6, no.3, pp.55-59.

Lyotard, J.-F. 1984, The Postmodern Condition: A Report on Knowledge, University of Minnesota Press, Minneapolis, MN.

MacFarquhar, N. 2010, 'Banks making big profits from tiny loans’, The New York Times. April 13, 2010.

Metcalf, T. 2006, A Concise History of Modern India, Cambridge University Press, Cambridge.

Morduch, J. 1999, ‘The microfinance promise', Journal of Economic Literature, vol. XXXVII December, pp.1569-1614.

Morduch, J. 1998,'The microfinance schism', World Development, vol.28, no.4, pp. 617-629.

Morduch, J. 2007, 'Online Extra - Microlending: It’s no cure-all’, Businessweek Online, December $13^{\text {th }}$.

Newsmaker 2008, 'The big problem in Indian journalism is the lack of quality and experience at the copy desk', http://www.nwmindia.org/Newsmakers/Sevanti.htm .

Otero, M. 1999, 'Bringing development back, into microfinance', Journal of Microfinance, vol.1, no.1.

Phillips, L. 1996, 'Rhetoric and the spread of the discourse of Thatcherism', Discourse \& Society, vol.7, no.2, pp. 209-241.

Parameswaran, R. 2004, 'Global queens, national celebrities: tales of feminine triumph in postliberalization India’, Critical Studies in Media Communication, vol. 21, no. 4, pp.346 - 37.

Peer, B. 2007, ' Style Over Substance: Despite India's media boom, its journalism is shrinking', Columbian Journalism Review, May / June http://www.cjr.org/feature/style over substance_1.php

Ramanathan, V. 2005, The English-vernacular divide: Postcolonial language politics and practice, Clevedon, Multilingual Matters.

Rhyne, E. 2001, 'Commercialisation and crisis in Bolivian Microfinance’, Development Alternatives, Inc., Bethesda, MA.

Riffe, D., S. Lacy \& F. Fico 2008, Analyzing Media Messages, Routledge.

Schreiner, M. 2003, 'A cost-effectiveness analysis of the Grameen Bank of Bangladesh', Development Policy Review, vol.21, no.3, pp. 357-382.

Scrase, T. 2004, 'The hegemony of English in India', in: R. Cribb (ed.), Asia examined: Proceedings of the 15th Biennial Conference of the ASAA, 2004, Canberra, Asian Studies Association of Australia \& Research School of Pacific and Asian Studies, The Australian National University.

Scully, N. 2004, Microcredit: No panacea for poor women, Global Development Research Centre, Washington, DC.

Simanowitz, S. 2002, 'Microfinance for the poorest: A review of issues and ideas for contribution of Imp-Act', Improving the impact of microfinance on Poverty: An Action Research Programme, University of Sussex, Brighton.

Sinclair, Hugh 2012, Confessions of a microfinance heretic: how micro-lending lost its way and betrayed the poor, Berrett-Koehler Publishers, Inc.

Siroya, Shivani 2010, 'The backlash in microfinance', The Huffington Post November 10, http://www.huffingtonpost.com/shivani-siroya/the-microfinance-backlash b 781431.html

Woller, G. M. 2002, 'The promise and peril of microfinance commercialization', Small Enterprise Development, vol.13, no.4, pp.12-21.

Woller, G. M., Dunford, C., \& Woodworth, W. 1999, 'Where to microfinance?’. International Journal of Economic Development, vol.1, no.1, pp. 29-64. 
Yunus, M. 2005, 'Social Business Entrepreneurs Are the Solution', Grameen Foundation USA Publication Series.

Yunus, M. 2001, 'Towards creating a poverty-free world', in Hossain, F. and Rahman, Z. (Eds.), Microfinance and Poverty: Contemporary Perspectives, Department of Administrative Sciences, University of Tampere, Tampere, pp. 21 -41.

Yunus, M. \& Jolis, A. 2003, Banker to the poor: Micro-lending and the battle against world, Public Affairs (Perseus), New York.

Zeller, M. \& Meyer, R.L. 2002, 'The triangle of microfinance: Financial sustainability, outreach and impact’, John Hopkins for the International Food Policy Research Institute. 